\title{
Research on the Determinants of Peasants'Land Mortgage in China
}

\author{
Ji Luo, Ying Wang ${ }^{*}$ and Fan $\mathrm{He}$ \\ School of Economics, Sichuan University of Science \& Engineering, Zigong, 643000 Sichuan, People’s republic of China \\ ${ }^{*}$ Corresponding author
}

\begin{abstract}
Based on the survey data of Peasants in China, the bivariate Probit model is constructed to analyze the factors affecting Peasants' land mortgage Determinants. The results show that the willingness of Peasants' land mortgage is higher, and the education level, the rationality of loan term and the understanding degree of the relevant policies have significant positive impacts on the needs of the mortgage. Moreover, the impact of cultivated land area, social insurance, family annual income and interest rate on the financing needs of different types of Peasants is different.
\end{abstract}

Keywords-land property rights; type of peasants; mortgage willingness; bivariate probit model

\section{INTRODUCTION}

Rural land property rights refer to the sum of rural land rights with the land ownership as the core. At present, under the framework of Peasant contract responsibility system, rural land property rights mainly refer to rural land contract management rights. "The Property Law" in 2007 clearly defined the rights of land contract management in the form of law at the first time. The law holds that the land contract management rights refer to use and income rights of cultivated land, forest land and grassland, and the rights to engage in farming, forestry, animal husbandry and other agricultural production [1].

Because China is a large agricultural country, the development of rural financial markets not only directly affects the economy of rural areas, but also affects the national macroeconomic development. For a long time, China's rural funds flow through different channels, resulting in rural loans far lower than the savings funds. In 2000 rural loans amounted to 654.97 billion Yuan, rural deposits reached 1235.53 billion Yuan, the deposit to loan balance reached 580.56 billion Yuan. In 2013 loans amounted to 8577.829 billion Yuan, while the rural deposits reached 10628.712 billion Yuan, and the difference was 2050.883 billion Yuan, the growth rate of difference has reached $253.25 \%$. With the rapid transformation of agricultural production mode to modernization, rural social economic development requires a lot of financial support. As the main rural financial market participants Peasants and small and medium agriculture-related enterprises gradually expand the demand for funds, the scope of demand is further widened. Due to a large number of outflows of rural funds, the financial needs are difficult to be effectively satisfied. According to the data released by the China Banking Regulatory Commission, at the end of 2008 the loan balance of agricultural related small and medium-sized enterprises by national financial institutions was 25880.13 billion Yuan, and 351.0718 million small and medium-sized enterprises received loans. In 2009, the corresponding data was 5112.98 billion Yuan and 290.1614 million. Compared to 2008, the amount of loans increased in 2009, but the number of small and medium-sized enterprises with loans reduced. The increase in the amount of loans indicates that the financing needs of rural small and mediumsized enterprises have been improved. Moreover, the reduction in the number of enterprises has shown that the coverage rate of loans has not been effectively mitigated, indicating that the funds have a tendency to focus on part of small and mediumsized enterprises. In terms of Peasants, the amount of loans in 2008 was 2508.39 billion Yuan, the number of Peasants to obtain loans was 7381.96 million. In 2009, the relevant data were 2557.26 billion Yuan and 7725.97 million, while the relevant data in recent years shows that the number of loans to Peasants remained 5.1\% of the national loan balance roughly.

In China, with the expansion of agricultural production scale, Peasants want to contract the land right to operate mortgage become increasingly strong [2,3]. Due to the limitation of the existing legal system [4,5,6], the high cost of disposal of land and the abolition of loan collateral foreclosures, the imperfect land property market [7] and other reasons result in the lack of funds from financial institutions and the limitation of actual participation of Peasants. Scholars are concerned about the factors that affect Peasants' participation in land mortgage, including demographic characteristics, family characteristics and financial environment. Demographic characteristics are gender, age, educational level, and working experience, etc. Family characteristics are family business type, labor force ratio, loan experience, investment projects, investment risk tolerance, social relations, arable land, geographical location, etc. Financial environment are interest rate level, loan term and so on. Such factors have a significant impact on Peasants' land mortgage participation willingness $[8,9]$. A small number of scholars are involved in the participation of Peasants. They believe that the educational level, cultivated land area, and the distance to the nearest financial institution affect the possibility of Peasants to apply for loan. Policy understanding, ease of transport and interpersonal relationships positively affect the loan rate [10]. There are also groundbreaking researches which divide behaviors into two kinds, behavioral response and response times. The researches show that the educational level, family structure, cultivated land area, distance of the nearest financial institution have influences on the behavioral response of 
Peasants, and the family structure also affects the response frequency of Peasants .

This paper study the determinants of peasants' land financing from the perspective of the different concurrent work, using the field survey data of rural areas in different regions of China. This paper might provide decision-making consultation to promote smooth implementation of rural land mortgage..

\section{DATA AND STATISTICAL DESCRIPTIONS}

The data are mainly from the questionnaire survey of Peasants in Wenjiang District of Chengdu, Hechuan District of Chongqing, Fenggang County of Zunyi, Tongxin County of Ningxia from July 2015 to February 2016. Researchers selected 3-5 townships randomly in each region. In each township they randomly selected 30-50 Peasants to do indepth interviews and fill in the questionnaire. In order to reduce the sample deviation, the number of Peasants in each township accounts for about $10 \%$ of the total number of Peasants in the townships, so that the regional data samples are evenly distributed. A total of 1180 questionnaires were issued by the above method, and 1121 questionnaires were collected, including 1006 valid questionnaires. The basic situation of Peasants surveyed in the sample area is shown in Table 1.

TABLE I. BASIC DATA OF PEASANTS SURVEYED IN THE SAMPLE AREA

\begin{tabular}{|c|c|c|c|}
\hline Category & Index & Number & Proportion \\
\hline \multirow{2}{*}{ Gender } & Male & 845 & $83.90 \%$ \\
\hline & Female & 161 & $16.10 \%$ \\
\hline \multirow{3}{*}{ Family Size } & $1-3$ & 334 & $33.20 \%$ \\
\hline & $4-6$ & 661 & $65.70 \%$ \\
\hline & $>=7$ & 11 & $1.10 \%$ \\
\hline \multirow{5}{*}{ Age } & $<=29$ & 48 & $4.77 \%$ \\
\hline & $30-39$ & 363 & $36.08 \%$ \\
\hline & $40-49$ & 410 & $40.75 \%$ \\
\hline & $50-59$ & 165 & $16.40 \%$ \\
\hline & $>=60$ & 21 & $2 \%$ \\
\hline \multirow{5}{*}{$\begin{array}{c}\text { Educational } \\
\text { Level }\end{array}$} & Illiteracy & 24 & $2.39 \%$ \\
\hline & Primary school & 213 & $21.17 \%$ \\
\hline & Junior high school & 572 & $56.86 \%$ \\
\hline & High school & 170 & $16.90 \%$ \\
\hline & College or higher & 27 & $2.68 \%$ \\
\hline \multirow{3}{*}{$\begin{array}{l}\text { Family } \\
\text { Type }\end{array}$} & $\begin{array}{c}\text { Professional } \\
\text { Peasants }\end{array}$ & 199 & $19.78 \%$ \\
\hline & $\begin{array}{c}\text { with one } \\
\text { concurrent job }\end{array}$ & 316 & $31.41 \%$ \\
\hline & $\begin{array}{c}\text { with two } \\
\text { concurrent job }\end{array}$ & 491 & $48.81 \%$ \\
\hline
\end{tabular}

Data are based on the survey by the research team.

Note: "Professional Peasants" refer to Peasants that nonagricultural income account for less than $10 \%$ of the total family income.

"with one concurrent job" refer to Peasants that nonagricultural income account for $10 \%$ to $50 \%$ of the total family income.

"with two concurrent jobs" refer to Peasants that nonagricultural income account for more than $50 \%$ of the total family income.
It can be seen from Table 1 that the surveyed Peasants are male mainly, accounting for nearly $84 \%$ of the total, reflecting the Chinese rural families are dominated by men. As for family size, a family population is mainly 4-6 people, accounting for $65.7 \%, 1-3$ of the family size accounts for $33.2 \%, 7$ or more of the family size accounts for only $1.1 \%$. It is indicated that Chinese rural families change from medium to small gradually. In terms of age level, the age is mainly 3049 years old. In terms of educational level, the illiteracy is very small, more than $76 \%$ of the respondents have received junior high school education or above. In terms of family type, the type of part-time Peasants is more common, mainly with two concurrent jobs, accounting for $48.81 \%$, followed by $31.41 \%$ of the Peasants with one concurrent job. In all the four districts visited, the proportion of professional Peasants is the smallest, with an average of less than $20 \%$, indicating that Chinese rural family type has a trend of change to the type of concurrent business, and concurrent work has become the main job, while agriculture becomes a family sideline.

TABLE II. DEMAND FOR LAND PROPERTY MORTGAGE OF DIFFERENT TYPES OF PEASANTS IN CHINESE RURAL

\begin{tabular}{lcccc}
\hline $\begin{array}{l}\text { Types of } \\
\text { Peasants }\end{array}$ & Number & Proportion & $\begin{array}{c}\text { Number } \\
\text { of } \\
\text { demand }\end{array}$ & $\begin{array}{c}\text { Proportion } \\
\text { of demand }\end{array}$ \\
\hline $\begin{array}{l}\text { Professional } \\
\text { Peasants }\end{array}$ & 199 & $19.78 \%$ & 183 & $91.96 \%$ \\
\hline $\begin{array}{l}\text { Peasants } \\
\text { with one } \\
\text { concurrent } \\
\text { job }\end{array}$ & 316 & $31.41 \%$ & 264 & $83.54 \%$ \\
\hline $\begin{array}{l}\text { Peasants } \\
\text { with two } \\
\text { concurrent } \\
\text { jobs }\end{array}$ & 491 & $48.81 \%$ & 362 & $73.73 \%$ \\
\hline \multicolumn{1}{c}{ Total } & 1006 & $100 \%$ & 809 & $80.42 \%$ \\
\hline
\end{tabular}

Note: the proportion $=$ different types of Peasants $/$ total Peasants, the proportion of demand $=$ number of different types of Peasants demand for land property mortgage / total number of the same type of Peasants

809 Peasants have pledged their willingness to finance, accounting for $80.42 \%$ of the total Peasants. The statistical analysis shows that the higher the degree of concurrent work of Peasants, the stronger the willingness to raise farmland mortgage. Specifically, $73.73 \%$ of the respondents in the Peasants with two concurrent jobs had the willingness to pledge their land, which is the lowest among all types of Peasants. While the proportion of Peasants with one concurrent job is $83.54 \%$, professional Peasant is $91.96 \%$. Our findings are different from those of Zhang Longyao (2015), which we will explain later.

\section{MODELS AND VARIABLES}

\section{A. Models}

Virtual variables $D_{i}$ and $S_{i}$ represent the Peasants' land mortgage demand and the financial supply from financial institutions, respectively $D_{i}=1$ means that Peasants have land mortgage needs, and vice versa as $D_{i}=0$. Similarly, 
$S_{i}=1$ means that financial institutions supply funds, and vice versa as $S_{i}=0$. There are four possible states, namely, "there is a loan demand, there is a supply of funds", "there is a loan demand, no capital supply", "no loan demand, a supply of funds", "no loan demand, no money supply". It can be expressed as $(1,1),(1,0),(0,1),(0,0)$. Where $(1,1)$ can be obtained directly by observations, which is the effective selection. $(1,0)$ can be obtained through a questionnaire survey, although it is an ineffective choice for Peasants, but we can know the willingness for financing. $(0,1)$ and $(0,0)$ are less meaningful for our research.

The ith Peasant's land mortgage behavioral function and financial institution supply function can be expressed as:

$$
\begin{gathered}
D_{i}^{*}=\alpha_{\eta} X_{i}+\varepsilon_{i} \\
D_{i}=\left\{\begin{array}{l}
1, D_{i}^{*}>0 \\
0, D_{i}^{*} \leq 0
\end{array}\right\} \\
S_{i}^{*}=\beta_{\sigma} Z_{t}+\mu_{t} \\
S_{i}=\left\{\begin{array}{l}
1, S_{i}^{*}>0 \\
0, S_{i}^{*} \leq 0
\end{array}\right\}
\end{gathered}
$$

$X_{i}$ and $Z_{i}$ are the factors that affect the Peasants' land mortgage and the funds supply by financial institutions respectively. $\varepsilon_{i}$ and $\mu_{i}$ are error terms in normal distribution, the correlation coefficient between them is $\rho$.

Assume that $P$ is a dummy variable of the Peasants involved in land mortgage. $P=1$ means they participate in the land mortgage, $P=0$ indicates that they do not participate in land mortgage.

$$
P=\left\{\begin{array}{l}
1, D_{i}=1 \text { and } S_{i}=1 \\
0, D_{i}=0 \text { or } S_{i}=0
\end{array}\right\}
$$

When the Peasant has demands of land mortgage $\left(D_{i}=1\right)$ and the financial institution has no funds to supply $\left(\left(S_{i}=0\right)\right)$.

$$
\operatorname{Pr}\left(D_{i}=1, S_{i}=0\right)=\Phi_{1}\left(a_{\eta} X_{i}\right)-\Phi_{2}\left(a_{\eta} X_{i}, \beta_{\sigma} Z_{i}, \rho\right)
$$

When the Peasant has demands of land mortgage ( $D_{i}=1$ ) and the financial institution has the capital supply $\left(S_{i}=1\right)$.

$$
\operatorname{Pr}\left(D_{i}=1, S_{i}=1\right)=\Phi_{2}\left(a_{h} X_{i}, \beta_{\sigma} Z_{i}, \rho\right)
$$

The maximum likelihood method is used to estimate (4) and (5). The logarithm likelihood function can be expressed as:

$$
\ln L=\sum_{i=1}^{N}\left\{\begin{array}{l}
D_{i} S_{i} \ln \Phi_{2}\left(a_{\eta} X_{i}, \beta_{\sigma} Z_{i}, \rho\right)+D_{i}\left(1-S_{i}\right) \ln \left[\Phi_{1}\left(a_{\eta} X_{i}\right)-\right. \\
\left.\Phi_{2}\left(a_{\eta} X_{i}, \beta_{\sigma} Z_{i}, \rho\right)\right]+\left(1-D_{i}\right) \ln \Phi_{1}\left(-a_{\eta} X_{i}\right)
\end{array}\right\}
$$

Where $\Phi_{1}(\bullet)$ is the cumulative standard normal distribution function, $\Phi_{2}(\bullet)$ is bivariate cumulative normal distribution function.

\section{B. Variables}

From the investigations of Huang Huichun (2015) and other related researchers, combined with the characteristics of the questionnaire variables that influence land mortgage behavior of Chinese Peasants are determined.

(1) Peasant characteristics: including 3 variables of age, educational level and loan experience. The higher the Peasant's age is, the lower the demand for mortgage is. The higher the degree of education is, the richer the loan experience is. At the same time, if the Peasant is under 60 years old, the older the age is, the higher degree of education he receives, and the more experienced in loan, the more easily the Peasant gets the trust of financial institutions to obtain loans.

(2) Family characteristics: including 5 variables of cultivated land area, support rate, family annual income, social resources and whether to buy insurance. It is expected that when the cultivated land area is larger, the demand for land mortgage of Peasants with endowment or medical insurance is higher. The Peasants with higher support rate have less willingness in land mortgage. The impact of family annual income and social resources on land mortgage demand is uncertain. From the perspective of financial institutions, Peasants with higher supply rate are more difficult to obtain loans. Peasants with larger cultivated land area, higher annual income and stronger social resources are favored by financial institutions.

(3) The characteristics of financial products: Peasants' land mortgage behavior is also related to the characteristics of the loan products. Three variables of the Peasants' assessment on interest rate, term of land mortgage and the understanding degree of the mortgage policy are selected to measure its impact. 
TABLE III. DEFINITION OF CORRELATIVE VARIABLES AND DESCRIPTIVE STATISTICS

\begin{tabular}{|c|c|c|c|c|}
\hline & Variables & Definition & Average & $\begin{array}{l}\text { Standard } \\
\text { deviation }\end{array}$ \\
\hline \multirow[t]{2}{*}{$\begin{array}{l}\text { Personal } \\
\text { willing }\end{array}$} & $\begin{array}{l}\text { Demands for } \\
\text { land } \\
\text { mortgage }\end{array}$ & $0=$ No, $1=$ Yes & 0.821 & 0.668 \\
\hline & Funds supply & $0=$ No, $1=$ Yes & 0.392 & 0.577 \\
\hline \multirow[b]{2}{*}{$\begin{array}{l}\text { Peasant } \\
\text { characterist } \\
\text { ics }\end{array}$} & Age & $\begin{array}{l}1=29 \text { years old } \\
\text { and below, } \\
2=30-39,3=40- \\
49,5=60 \text { and } \\
\text { above }\end{array}$ & 2.901 & 1.273 \\
\hline & $\begin{array}{l}\text { Educational } \\
\text { level }\end{array}$ & $\begin{array}{l}\text { 1=Illiteracy, } \\
\text { 2=Primary } \\
\text { school, } \\
\text { 3=Junior high } \\
\text { school, 4=High } \\
\text { school, } \\
\text { 5=College and } \\
\text { above }\end{array}$ & 3.266 & 0.893 \\
\hline \multirow{4}{*}{$\begin{array}{l}\text { Family } \\
\text { characterist } \\
\text { ics }\end{array}$} & Support rate & $\begin{array}{l}\text { Continuous } \\
\text { variable }\end{array}$ & 0.325 & 0.511 \\
\hline & $\begin{array}{l}\text { Cultivated } \\
\text { land area }\end{array}$ & $\begin{array}{l}\text { Continuous } \\
\text { variable }\end{array}$ & 1.731 & 1.354 \\
\hline & $\begin{array}{l}\text { Social } \\
\text { insurance }\end{array}$ & $0=$ No, $1=$ Yes & 0.898 & 0.542 \\
\hline & $\begin{array}{l}\text { Family } \\
\text { annual } \\
\text { income }\end{array}$ & $\begin{array}{l}\text { Continuous } \\
\text { variable }\end{array}$ & 13.679 & 2.862 \\
\hline \multirow{4}{*}{$\begin{array}{l}\text { Financial } \\
\text { product } \\
\text { assessment }\end{array}$} & $\begin{array}{l}\text { Interest rate } \\
\text { level }\end{array}$ & $\begin{array}{l}\text { 1=Low, } \\
\text { 2=Moderate, } \\
\text { 3=High }\end{array}$ & 2.421 & 0.635 \\
\hline & Loan term & $\begin{array}{l}\text { 1=Very } \\
\text { unreasonable, } \\
\text { 2=Unreasonable } \\
\text {, 3=General, } \\
\text { 4=Reasonable, } \\
\text { 5=Very } \\
\text { reasonable }\end{array}$ & 3.017 & 1.225 \\
\hline & & $\begin{array}{l}\text { 1=Don’t } \\
\text { understand } \\
\text { completely }\end{array}$ & & \\
\hline & $\begin{array}{l}\text { Understandin } \\
g \text { of land } \\
\text { mortgage } \\
\text { policy }\end{array}$ & $\begin{array}{l}\text { 2=Don't } \\
\text { understand } \\
\text { basically, } \\
\text { 3=Understand } \\
\text { basically, } \\
\text { 4=Understand } \\
\text { completely }\end{array}$ & 2.871 & 0.644 \\
\hline
\end{tabular}

Data are based on the survey by the research team.

Note: 1 . Support rate $=$ families with persons that are over 60 years old and uninhabited children / total population of the family

2. Social resources $=1$, families with relatives or friends work in government departments or financial institutions. On the contrary, social resources $=0$

Finally, complete content and organizational editing before formatting. Please take note of the following items when proofreading spelling and grammar:

\section{EMPIRICAL RESULTS}

The bivariate Probit model set by equations (4) and (5) is used to test the influencing factors of land mortgage behavior of Peasants in different degree of part time in China. The results are shown in Table 4. From the regression results of Table 4, it was found that the values $\rho$ of professional Peasants, Peasants with one concurrent job and Peasants with two concurrent jobs were $-0.859,-1.159$ and -1.077 respectively, and the likelihood ratios were significant, indicating that there are simultaneous relations between equations (4) and (5).

TABLE IV. ESTIMATION BASED ON THE BIVARIATE PROBIT MODEL

\begin{tabular}{llll}
\hline Name & $\begin{array}{l}\text { Professional } \\
\text { Peasants }\end{array}$ & $\begin{array}{l}\text { Peasants with } \\
\text { one concurrent } \\
\text { job }\end{array}$ & $\begin{array}{l}\text { Peasants with } \\
\text { two } \\
\text { concurrent } \\
\text { jobs }\end{array}$ \\
\hline Constant & -66.812 & -7.551 & -22.174 \\
\hline Age & $0.197^{* * *}$ & $0.128^{* *}$ & $0.975^{* * *}$ \\
\hline $\begin{array}{l}\text { Educational } \\
\text { level }\end{array}$ & $20.166^{* *}$ & $0.877^{* * *}$ & $0.717^{* *}$ \\
\hline Support rate & $-0.386^{* *}$ & $3.638^{* *}$ & $-0.109^{*}$ \\
\hline $\begin{array}{l}\text { Cultivated land } \\
\text { area }\end{array}$ & $0.066^{*}$ & $0.207^{*}$ & 0.011 \\
\hline $\begin{array}{l}\text { Social } \\
\text { insurance }\end{array}$ & $0.080^{* *}$ & $2.058^{* *}$ & 0.269 \\
\hline $\begin{array}{l}\text { Family annual } \\
\text { income }\end{array}$ & $0.067^{* *}$ & 0.067 & $0.980^{* *}$ \\
\hline Interest rate & 0.048 & 0.174 & $-0.501^{* *}$ \\
\hline Loan term & $0.261^{* * *}$ & $0.759^{* * *}$ & $0.443^{* * *}$ \\
\hline $\begin{array}{l}\text { Understanding } \\
\text { of policy }\end{array}$ & $0.400^{* *}$ & $1.345^{* *}$ & $2.651^{* *}$ \\
\hline$\rho$ & $-0.859^{* *}$ & $-1.159^{* *}$ & $-1.077^{* *}$ \\
\hline $\begin{array}{l}\text { Maximum } \\
\text { likelihood } \\
\text { value }\end{array}$ & -34.223 & -65.052 & -118.918 \\
\hline $\begin{array}{l}\text { Observation } \\
\text { value }\end{array}$ & 183 & 265 & 361 \\
\hline
\end{tabular}

(1) Age has a significant impact on the loan demand of the three types of Peasants, but in different directions. For professional Peasants, the older they are the more they are accustomed to the current state of production and life, because of the desire to avoid the risk rather than land mortgages. The part time Peasants are more engaged in non-agricultural production. For them, the land dependence is lower, the understanding of market is stronger, and with the increase of knowledge and experiences, they have more consciousness and initiative to obtain funds for land mortgage to expand the scale of production.

(2) Educational level has a significant positive impact on land mortgage behavior of different types of Peasants. The higher the degree of education is, the higher the degree of understanding and acceptance of new things is. The stronger the willingness to start a business is, the more willingness to mortgage the land in the case of funding constraints.

(3) The support rate has a significant negative impact on the land mortgage behavior of professional Peasants and part time Peasants. The higher the support rate is, the higher the burden on Peasants is. Especially for professional Peasants and Peasants with one concurrent job whose income are major from agriculture, land dependence is strong and is not willing to take risks to mortgage land for living security.

(4) The cultivated land area has a significant positive impact on the demand for land mortgage of professional 
Peasants and Peasants with a concurrent job. The effect on the Peasants with two concurrent jobs is positive but not significant, indicating that the larger the cultivated land area is, the higher the willingness to land mortgage is. The larger the cultivated area is, the higher the agricultural production investment is, the more likely to face the shortage of funds, thereby increasing the Peasants' mortgage needs.

(5) Social insurance only has significant effect on professional Peasants and Peasants with one concurrent job, but also has influence on Peasants with two concurrent jobs in the same direction. It shows that the rural social endowment insurance can reduce the protective function of land to a certain extent and enhance the Peasants' land mortgage willingness.

(6) The family annual income has a significant positive impact on the land mortgage behavior of professional Peasants and Peasants with two concurrent jobs. Although Peasants with a concurrent job do not pass the significance test, the influence direction is the same.

(7) The loan term and the understanding of policy have a significant impact on different types of Peasants, while the interest rate level only has obvious effect on the Peasants with two concurrent jobs. Because the income of Peasants with two concurrent jobs is higher, financing channels are broader, so they are more sensitive to interest rate. For both professional Peasants and Peasants with one concurrent job, although high interest rates increase the cost of loans and curb their financing needs to a certain extent, but when they face with financial difficulties, interest rates are not the main factors they consider, but rather pay more attention to loan term. This has a relationship with the cyclical nature of agricultural production. When the loan term is matched with the agricultural production, the Peasants can not only solve the problem of shortage of funds, but also ensure the repayment of the production income on time and effectively avoid the loan risk.

\section{POLICY RECOMMENDATIONS}

Based on the above conclusions, in order to effectively solve the current problems of financing in China's rural areas, and further promote the orderly operation of mortgage of China's rural land contract rights, the following recommendations are proposed.

(1) The possible risk of mortgage is always an important factor for Peasants to consider in mortgage decision-making. Government departments should further improve the risk prevention and sharing mechanism of Peasant's land mortgage at the institutional level from the perspective of Peasants.

(2) To build a scientific and rational evaluation system of rural land and improve the land assessment services. To strengthen the training and publicity of land mortgage related knowledge of the Peasants. To promote the formation of a correct understanding of land mortgage. To further improve the level of social security of Peasants, narrow the gap in the rural and urban health care, pension and other aspects, in order to reduce worry of the Peasants.
(3) To increase the policy support to the rural financial institutions. On the one hand, it is effective to reduce the land mortgage transaction cost by standardizing the rural land circulation market under the premise of doing well in the land right confirmation, registration and certification. On the other hand, we should actively cultivate new rural financial institutions (such as village banks, small loan companies, etc.), build a diversified rural financial system, and increase credit support for Peasants, especially the professional Peasants with low income.

\section{REFERENCES}

[1] Zhong Yuanping. The Jurisprudential Bases of China's Rural Land Trust and the Formation of the Concrete Systems of the Trust [D]. China University of Political Science and Law, Beijing, 2007, 13-15.

[2] Wang Ping, Qiu Daochi, Li Guangdong. Study on the Requirements of Rural Land Mortgage Loan Based on Peasants Willingness [J]. Chinese Journal of Agricultural Resources and Regional Planning, 2012, 33(2): 73-77.

[3] Yu Hongli, Chen Jinli, Lan Qinggao. Analysis of the Household's Demand to Rural Land Management Rights Mortgage Financing: Based on a Survey of 385 Peasants in Liaoning Province [J]. Issues in Agricultural Economy, 2014(3): 25-31.

[4] Wang Xiansheng, Guo Zhongxing. Land Contract Management Right Mortgage: Powers Separation and Operation Mechanism - Based on the Investigation of Xinyi County in Jiangsu Province and Tongxin County of Ningxia [J]. Economist, 2014(4): 49-60.

[5] Zhong Funing, Ji Yueqing. Land Rights, Non-agricultural Employment Opportunities and Peasants, Agricultural Investment [J]. Economic Research Journal, 2009, 12(43): 15-23.

[6] Zhao Zhenyu. Study on the Mortgage of Rural Land Contract Management Rights Based on Different Management Subjects [J]. Management World, 2014(6): 174-175.

[7] Huang Huichun, Qi Yan, Cheng Lan. Rural Land Contracting Right Mortgage Loan and Credit Access: An Empirical Analysis Based on Cluster Matched Pairs [J]. Economic Review, 2015(3): 72-83.

[8] Yang Titing, Luo Jianchao. Empirical Research on the Influencing Factors of the Peasant's Willingness on the Rural Property Mortgage Based on 919 sample Peasants in Gaoling County of Sahnxi and Tongxin County of Ningxia [J]. Chinese Rural Economy, 2014(4): 51-54.

[9] Hui Xianbo. The Analysis of Potential Demands and Influential Factors of Peasants' Land Contracted Management Right Mortgage Loan: Based on the Empirical Analysis of Four Pilot Counties in Henan Province [J]. Issues in Agricultural Economy, 2013(2): 9-15.

[10] Niu Rong, Zhang Hang, Luo Jianchao. Research on the Peasants' Credit Constraints under Rural Property Mortgage [J]. Issues in Agricultural Economy, 2016(1): 76-83. 